Araştırma Makalesi / Research Article

\title{
BİR ZAMANLAR BOLU İKINCI AMELE TABURU (1914-1918)
}

\author{
Abdullah LÜLECI* \\ ONCE UPON A TIME THE SECOND LABOR BATTALION \\ OF BOLU (1914-1918)
}

\begin{abstract}
$\ddot{\mathbf{O} z}$
Savaşlar, farklı strateji ve hamleleri barındıran süreçlerdir. Osmanlı Devleti için I. Dünya Savaşı; birçok uygulama ve planın devreye sokulduğu uzun ve yorucu bir dönemi kapsamaktadır. Bu büyük savaşta; farklı stratejilere ek olarak daha önce Balkan Savaşlarında benzer örnekleri görülen amele taburu uygulamasına müracaat edilmiştir. Anadolu'nun farklı yerlerinde kurulan yüzden fazla amele taburundan biri de mevcudunda dönemsel değişiklikler görülen ve birbirlerinden kilometrelerce uzak bölgelerde görev yapan Bolu İkinci Amele Taburu'dur. Bu tabur mensupları; günlerce yol yürümek zorunda kaldıkları, salgın hastalıklarla mücadele ettikleri, yeterli konaklama ve beslenme konusunda sıkıntı yaşadıkları için zaman zaman firar etmeye kalkışsalar da gerek karayolu gerekse demiryolu yapım ve tamirindeki çalışmalarıyla savaş sırasında orduya, sonrasında da sosyal çevreye ciddi katkı sağlamışlardır.
\end{abstract}

Anahtar Kelimeler: Bolu, Amale Taburu, I. Dünya Savaşı, Geri Hizmet.

\begin{abstract}
Wars are processes that involve different strategies and moves. The First World War for the Ottoman Empire covers a long and exhausting period in which many applications and plans were put into operation. In this great war, in addition to different strategies, labor battalions were applied, similar applications had also been applied during the Balkan Wars. One of the more than a hundred working battalions that were established in different parts of Anatolia was the second Labor Battalion of Bolu, which had seen periodic changes in its existence and was serving in regions that were miles away from each other. Members of this battalion were forced to walk for days on the road, they were fighting against epidemic diseases, adequate accommodation and nutrition. They were distressed from time to time about trying to escape from the Army. During the war in the road and railway construction and repair works, and in the post war period they provided a serious contribution to the social environment.
\end{abstract}

Keywords: Bolu, Labor Battalion, World War I, Deployed-in Garrison.

* Dr. Öğr. Üyesi, Bolu Abant İzzet Baysal Üniversitesi, e-posta: abdullahluleci@ibu.edu.tr, https://orcid.org/0000-0002-3723-7015.

Makale Gönderim Tarihi: 24.08.2020 https://doi.org/10.11616/basbed.v20i56819.784857 Makale Kabul Tarihi $\quad: 17.09 .2020$ 


\section{Giriş}

Devletlerin gücünü ortaya koyan önemli göstergelerden biri ordularıdır. Devletler, orduları sayesinde kendilerinden söz ettirmeyi başarırlar. Yüzyıllar boyunca farklı kitalarda hâkimiyet kuran Osmanlı Devleti de ordu sistemi sayesinde topraklarını genişletmiş ya da korumaya çalışmıştır. Osmanlı Devleti için tarihin her döneminde önemli ve kutsal sayılan ordunun asker ihtiyacı siyasî konjonktüre göre değişiklik gösterirdi. Zira Tanzimat Dönemi'ne kadar zorunlu bir askerlik uygulamasından ve gayrimüslimlerin orduya dâhil edilmesinden bahsetmek mümkün değildi. Lakin emperyalizm ve lokal milliyetçilik kıskacında kalan devlet, bünyesinde barındırdığ 1 farklı din ve kültüre sahip toplulukları bir araya getirerek millî bir kimlik oluşturmak hedefine yöneldi. Milli kimlik yaratma sürecinde gerek mevcut tehlikelerin önlenmesi gerekse toprakların korunması için askerlik alanında yeniliklerin yapılması kaçınılmaz olmuştur. Osmanlı vatandaşlarını kanun önünde eşit sayan Islahat Fermanı'na rağmen alışılmış bir durum olmayan gayrimüslim unsurların askere alınması, 1909 yılında yasalaştı. Her ne kadar yeni askerlik kanunu olan “Anasır-ı Gayrimüslimlerin Kur'aları Hakkında Kanun" ile Osmanlı toplumunda eşitlik ve vatandaşlık duygusu oluşturma amaçlanmışsa da zaman içinde bu kanun, birtakım zorlukları beraberinde getirdi (Kurtaran, 2012: 2270-2271; Lüleci, 2017: 1401; Şimşek, 2015: 209-210; Hacısalihoğlu, 2007: 60-63).

Ordunun asker ihtiyacını karşılama yönteminde yaşanan ciddi dönüşüme rağmen devlet erkânı, hazineye önemli bir gelir beklentisiyle gayrimüslimlerin bedel karşıllı̆ında askerlikten muaf tutulmalarına bir müddet daha imkân tanıdı. ${ }^{1}$ Nakdi bedel ödemeyenler ise ordu bünyesinde görevlerini icra ediyorlardı. Bu esnada gayrimüslimlerden bazılarının itaatsizlik, firar, casusluk ve birtakım disiplinsizlik olaylarına karıştıkları görüldü. Ancak tüm bu olumsuzluklara rağmen Mayıs 1914 tarihli düzenlemeyle Osmanlı tabiiyetindeki herkesin askerlik vazifesiyle mükellef olduğu kanun kapsamına alındı. Savaştan önceki son şekliyle Osmanlı hanedanının dışında herkes askerlikle mükellefti ve silahlısilahsız hizmet gruplarına ayrılıyordu. Askerlik alanındaki modernleşme hamleleriyle seferberliğin Müslim ve gayrimüslim unsurların tamamını kapsamasının ardından, 1894-1900 doğumlu gençler silahaltına çağrıldı.

\footnotetext{
${ }^{1}$ Bolu Ermenilerinden olan Gı̆̆mes Hopyan, gayri musallah askerlik kanunundan kırk dört Osmanlı Lirası ödeyerek muaf tutulduğunu belirtmektedir. Ayrıca gayri musallahtan kasıtın Amele Taburları olduğu ifade edilmektedir. Takvor Hopyan, Milleti Sadıka'dan 1915 Ermeni Tehciribe Pederimin Anıları, Puslu Yayınevi, İstanbul 2017, s. 21, 28.
} 
$\mathrm{Bu}$ çağrı doğal olarak on dört-yirmi yaşları arasındaki bütün Osmanlı vatandaşlarını kapsıyordu. ${ }^{2}$ Birkaç ay sonra ise kırk beş yaşına kadar olan vatandaşların tamamının askerlikle mükellef olduğu belirtilerek kanun kapsamı genişletildi (Beyoğlu, 2014: 2; Güler, 1996: 69-73; Özdemir, 1994: 25-30)

Osmanlı gündemini bir hayli meşgul eden askeri düzenlemeler sırasında Avrupa'da yaşanan devletlerarası krizler ve ikili çatışmalar savaşın kapılarını aralamıştı. Avusturya-Macaristan veliahdının Saraybosna gibi Osmanlı'ya yakın bir coğrafyada bir Sırplı tarafından öldürülmesi, geniş çaplı büyük bir savaşın fitilini ateşlemiş ve Osmanlı Devleti'ni seferberlik ortamına sokmuştur (Gülboy, 2004: 79-88, 142-146).

\section{I. Dünya Savaşı ve Amale Taburları}

Savaş hazırlıklarına Tanzimat Dönemi'nden itibaren yapılan askerî yeniliklerle giren Osmanlı ordusu; 2 Ağustos 1914'te seferberliğin ilan edilmesiyle silahlı ve silahsız hizmet sınıflarına ayrıldı. Bu sınıflandırmada gayrimüslim unsurların daha çok silahsız hizmet grubunu oluşturmalarına özen gösterildi. Çünkü bu husus Harbiye Nezaretinin 3 Ağustos 1914 tarihli direktifinde geçmekteydi. Vakit kaybetmeden gayrimüslimlerin geri hizmet birlikleri olan amele taburlarına gönderilmeleri amaçlandı. Hatta silahlı hizmet grubunda yer alan bazı gayrimüslim unsurların silahlarıyla birlikte firar olaylarına karışmaları, gayrimüslim unsurların amele taburlarına gönderilmelerini hızlandırdı.

Seferberliğin ilanından sonra kurulan amele taburları, silahlı hizmet grubu için uygun olmayan ve askerlik çağına göre nispeten yaşlı kimselerden oluşuyordu. Bu taburların öncelikli görevleri; askerî ve sivil sahalarda yol ve köprü inşa ya da tamir etmek, askerî-ziraî faaliyetlerde bulunmak ve ordu güzergâhını hazır hâle getirmekti. Savaş boyunca bu gibi farklı

\footnotetext{
${ }^{2} \mathrm{Bu}$ esnada bazı Yezidi ve Dürzîler askerlik hizmeti hususunda muafiyet elde etmişlerdir. Osmanlı Devleti'ne asker vermemek için ayaklanan bilhassa Havran ahalisi Dürzîler, askerlikten ve vergiden muaf tutulmuşlardır. Cengiz Mutlu, Birinci Dünya Savaşı'nda Amele Taburları (1914-1918), IQ Kültür Sanat Yayıncılık, İstanbul 2007, s. 38-39; Ayrıca seferlik öncesi ve sonrasında yürürlüğe giren geçici kanunlarla bedel-i nakdi ödemek şartıyla gayrimüslim unsurların askerlikten muaf olunacağı kararlaştırılmıştır. Zekeriya Özdemir, I. Dünya Savaşında Amele Taburları, Gazi Üniversitesi Sosyal Bilimler Enstitüsü Basılmamış Yüksek Lisans Tezi, Ankara 1994, s. 27-28. Tüm bunlara karşın bedel-i nakdi nedeniyle askerlikten muaf olanların en azından altı ay kadar eğitim almaları zorunluydu. a.g.t. s. 30. Öte yandan savaş sırasında sekiz, on ve on iki aylık askerlikten muaf sahte tezkerelere sahip Ermeni ve Türk gençlere rastlanılmıştır. Hopyan, a.g.e., s. 142, 156.
} 
görevler üstlenen amele taburlarının sayısı yüz yirmi altıya ulaştı. Her biri dörder bölüklü olan taburların başına Balkan Savaşlarının ardından emekliye ayrılmış ya da görevde bulunmamış ihtiyat subayları vazifelendirildi. Hemen hemen yüz bin kişinin görev yaptığ 1 taburların her birinin 1200 mevcutlu olacağı düşünülmüşse de zamanla sayılarında azalma $^{3}$ ya da çoğalmalar meydana geldi. Savaş koşulları ve kolordunun ihtiyacına göre sayıları değişiklik gösteren amele taburlarının kuruldukları bölgelerin isimlerini aldıkları da görülmüştür. $\mathrm{Bu}$ taburların askerî bir hamle ya da plan gereği, ordunun bölgedeki ikmal durumunu sağliklı ve sorunsuz hâle getirmek için de kuruldukları bölgelerden kilometrelerce uzakta bulunan askerî ya da sivil sahalara görevlendirildikleri olmuştur (Özdemir, 1994: 30-35, 81; Karagöz, 2019: 382). ${ }^{4}$

Osmanlı Devleti'nin I. Dünya Savaşı'nda birçok cephede düşmanla savaşması lojistik işlerini zorunlu kıldığından amele taburları, vakit kaybetmeksizin çalışma sahalarına gönderildi. Bu şekilde Anadolu'nun farklı yerlerinde oluşturulan geri hizmet birliklerinden biri de Bolu Birinci Amele Taburu'dur. Birinci Ordu Menzil Müfettişliğine bağlı olarak 28 Kasım 1914 ile 2 Ağustos 1917 tarihleri arasında Ereğli mevkiinde konuşlandırılan Tabur ${ }^{5}$, Zonguldak Kumandanlığının emrine verildi. Bahsi geçen dönemde geri hizmet birliği olarak görevlendirilen Tabur, TemmuzAğustos 1915 tarihini kapsayan yaklaşık bir aylık dönemde bin iki yüz elli dört sayısına ulaştı. Gezici bir misyona sahip olan ve bir ara Bahçeköy’de bulunan Bolu Birinci Amele Taburu; yüz seksen iki Müslüman, yüz doksan sekiz Rum, iki Yahudi ve sekiz yüz yetmiş iki Ermeni’den oluşan nüfusuyla Birinci Ordunun Avrupa yakasındaki önemli bir hizmet taburu haline dönüştü. Tabur içindeki sayılar dikkate alındığında gayrimüslim unsurların Müslümanlara oranla bir ara ciddi bir çoğunluğa sahip olduğu anlaşılmaktadır. Ancak bazı Ermeni unsurların 27 Mayıs 1915 tarihli Sevk ve İskân Kanunu'na tabi olmasıyla ilerleyen dönemde Taburun nüfusu dört yüz kırk sekiz nefere indi (Genelkurmay Atase Arşivi. BDH. 2534-32-131; Özdemir, 1994: 37, 47-48). Tabur mevcudunda dönemsel değişiklikler görülse de ordunun iaşe ve kömür tedarikinin sağlanması için yol yapım ve tamiri çalışmalarında ciddi hizmetleri oldu (Evcin, 2011: 67; BDH.

\footnotetext{
${ }^{3}$ Azalmaların önemli nedeni savaş esnasında yaşanan firar, izinlere itaatsizlik ve kayıp olaylarıdır. Özdemir, a.g.t., s. 61.

${ }^{4}$ Amele taburları; Harbiye Nezareti tarafindan Ordu ve Menzil Müfettişliği Amele Taburları ve Askeri Demiryolları ve Limanları Müdürlüğü ile Levazımat-1 Umumiye ve Karargâh-1 Umumiye Şimendifer Şubesi şeklinde iki farklı idari taksimata ayrılmışlardır. Daha çok ilk üç ordu bölgesi olmak üzere dört ordu mıntıkasında görevlendirilmişlerdir. Özdemir, $a$,g,t., s.35-36.

5 Taburun üçte biri Bolu'da bulunmaktaydı. a.g.t., s. 37.
} 
2534-32-1-31). Bu kapsamda Dersaadette bulundukları sirada Harbiye Nezareti'nin yönlendirmesiyle, Karadeniz sahilinde bulunan ve büyük önem arz eden Zonguldak-Devrek yolunun yapımı için bölgeye intikali istendi. Bölgeye yapılan bu görevlendirmenin asker, silah, cephane ve erzak ikmali için stratejik öneminin dışında, düşmanın ilerlemesine ve taarruz etmesine mani olmak gibi amaçları da vardı (BOA. DH. ŞFR. 472/53).

Hava şartlarının çalışmaya elverişli olduğu 1915 yılının yaz ve sonbahar günlerinde çalışmalarına aralıksız devam eden Taburun, kış aylarında çalıştırılamayacak olmaları hasebiyle farklı bir vilayete nakli kararlaştırıldı. Bu kararın alınmasında sert geçen kış günlerinde erzak ihtiyacının artacak olması da etkili olmuştur. Bu uygulamadan Zonguldak'taki Mevaki-i Müstahkeme ve Darüssanayi-i Askeriyede istifade edilen ameleler hariç tutuldu. Kış sebebiyle nakledilen amelelerin, hava şartlarının normale döneceği 1916 yılının Mart ayı ortalarına doğru tekrar bölgeye intikali istendi (BOA. DH. İ. UM. 59/1). Söz konusu nakil ve görevlendirme sırasında amelelerin zaman zaman başvurduğu ve Anadolu'nun farklı bölgelerinde kurulan taburlarda da görülen firar olayları, tedbirleri beraberinde getirdi. Bu kapsamda Dâhiliye Nezareti duruma dikkat çekerek bilhassa Konya ve Hüdavendigar vilayetleriyle İzmit, Bolu ve Karahisar-1 Sahib mutasarrıflıklarına yaşanan firar olaylarının engellenmesi, firarilerin yakalanması konusunda gerekli hassasiyetin gösterilmesi gerektiğini bildirmiştir (BOA. DH. EUM. KLU. 6/39).

\section{Bolu İkinci Amele Taburu ve İstanbul'a Hareketi}

Savaşlarda cephelerin olduğu kadar cephe gerisi ve lojistiğin savaşların kaderini etkilediği, hatta bu nedenle çoğu cephelerde askerlerin düşman ordularıyla karşılaşmadan etkisiz hâle geldiği Kafkas cephesinde yaşanan elim hadiselerle kanıtlanmıştır. Bu türden hadiselerin yaşanmaması ya da tekerrür etmemesi için devletler cephelere olduğu kadar cephe gerilerine ve lojistiğe ehemmiyet verme yoluna gitti.

Bu kapsamda Osmanlı Devleti'nin idari merkezi olan İstanbul'un Anadolu topraklarına açılan kapısı mahiyetindeki Bolu, jeopolitik durumundan dolayı geri hizmet birlikleri için önemli bir tercih sebebi oldu. Birden çok cephede mücadele ediliyor olması ve ordunun asker, silah, cephane ve erzak ikmali için yeni köprü ve yollara ihtiyaç duyması üzerine Bolu bölgesinden yeni bir amele taburu meydana getirilmiştir. Bu maksatla kurulan ve Birinci Ordu Kumandanlığının Birinci Menzil hizmetine verilen Bolu İkinci Amele Taburu, öncelikle başkent İstanbul'da ŞileÜsküdar yolunun onarımı için görevlendirildi. İstanbul'a 16-17 Mayıs 
1916 tarihinde hareket eden Taburda; sonradan değişiklikler olsa da başlangıçta sekiz subay, yedi yüz kırk beş nefer ve on dokuz yük hayvanı bulunuyordu. Düzce istikameti üzerinden tercih edilen yolculuğun bir program dâhilinde olmadığı göze çarpmaktadır. Zira Taburun İzmit'e ulaştığında Maltepe ya da Haydarpaşa'ya trenle mi yoksa yaya olarak mı geçeceği, amelelerin iskân ve iaşelerinin nasıl temin edileceği gibi konular Tabur bölgeye ulaşmadan çok evvel gündemi epey meşgul etmiştir (BDH. 2540-59-1; BDH. 2540-59-1-1; BDH. 2540-59-1-4).

Yüzlerce ameleden oluşan kafilenin yolculuk sırasında uğrak yerlerinin başında Adapazarı gelmekteydi. 25 Mayıs 1916 tarihinde yaklaşık bir haftalık uzun ve yorucu bir yolculuktan sonra Adapazarı'na ulaşan Tabur, bir müddet burada kaldı. Taburun bölgede konaklamasının birkaç sebebi vardı. Bunlardan biri Adapazarı'na ulaştıktan sonra İzmit'e sevk emrinin bildirilmemesiydi. Yazışmalardan kaynaklanan olumsuz bir durum gibi gözükse de yaya olarak sürdürülen yolculuğun kafileyi oldukça yorgun düşürmesi, istirahat amacıyla beklenildiğini akla getirmektedir. Diğer taraftan yol güzergâhı konusunda yaşanılan sıkıntılar da Taburun bir müddet Adapazarı'nda konaklamasının nedenleri arasındaydı. Ancak her ne kadar yol güzergâhı bildirilmiş olsa da bölgede yaşanılan salgın hatalıklar seyahate büyük bir engel teşkil ediyordu. Bu sırada sığır vebasından dolayı Arifiye'ye kadar olan kısım kordon altına alınmıştı. Salgın hastalık vakalarının önüne geçilmesi ve mevcut gayri sıhhî ortamların bertaraf edilmesi maksadiyla yapılan karantina uygulamalarından kaynaklı gecikmelere ilaveten kaymakamlık makamından nakliye araçlarının iadesinin istenmesi, Taburun hareketini engelleyen diğer bir durumdu.

Adapazarı'ndan hareketi konusunda yaşanan muammadan bir müddet sonra, Taburdan İzmit'e hareket tarihini bildirmeleri istendi. Tabur, İzmit'e ulaştıktan sonra hareket tarihlerini bildirmek kaydıyla sahil yolunu takip ederek Maltepe'ye ulaşacak ve yetecek miktarda iaşe için mahalli yönetimle irtibata geçecekti.

Tüm bu hazırlık ve talimatların ardından sekiz subay, yedi yüz kırk beş nefer, on dokuz hayvan ve on ton eşyasıyla Bolu İkinci Amele Taburu'nun Adapazarı'nda harekete hazır bir hâlde beklediği ve 11 Haziran 1916 tarihinde hareket edeceği bildirildi. Hareket sırasında iki günlük kumanyanın temin edilmesi gerektiği de vurgulanmıştır (BDH. 2540-591-6; BDH. 2540-59-1-8; BDH. 2540-59-1-9; BDH. 2540-59-1-13; BDH. 2540-59-1-14; BDH. 2540-59-1-15; BDH. 2540-59-1-17; BDH. 2540-591-18; BDH. 2540-59-1-23). 
Bu arada Adapazarı'nda yaşanan gelişmelerden olsa gerek Taburun ileriki dönemde karşılaşabileceği sıkıntılar/problemler üzerine değerlendirmeler yapılmıştır. Bilhassa Taburun, İstanbul'a ulaştığında konaklama için çadır ihtiyacının doğabileceği düşünülmüştür. Bu kapsamda herhangi bir sorunla karşılaşmamak adına, Tabur envanterinde ne kadar çadır bulunduğuna dair çalışmalar yürütülmüş̧ür. Tabur Kumandanı Mehmed Nihad'ın konuyla ilgili yaptığı açıklamada, kullanılmış ve tamamı yıpranmış olan on dört adet çadırın tabur bünyesinde bulunduğu bilgisi paylaşılmıştır. Taburun, Haydarpaşa'ya ulaştığında konaklama için mevcut çadırlar yeterli olmadığından, çözüm olarak bir gece Haydarpaşa' da konaklama ve iaşeleri sağlandıktan sonra Sultan Çiftliği Nokta Kumandanlığı emrine sevkleri istendi (BDH. 2540-59-1-26; BDH. 2540-59-1-27).

Yapılan yazışmalardan sonra Bolu İkinci Amele Taburu, yedi yüz elli yedi mevcutla ve iki günlük kumanya ile Adapazarı'ndan saat sekiz treniyle 13 Haziran 1916'da Tuzla'ya gelerek karantinaya tâbi tutuldu. Karantina süresinin bitmesiyle Tuzla'dan hareket etmeleri istenen Taburun, bir günlük karantina gecikmesinden sonra, ilk etapta elli sekiz neferinin Yüzbaşı Hüseyin Efendi kumandasıyla, altı yüz doksan neferinin de bir sonraki gün Keşan vapuru ile Haydarpaşa'ya ulaşacağı bildirildi. Buna karşın arabalı vapurla Haydarpaşa'ya geleceği bildirilen Taburun önce Sirkeci'ye ulaştığı ardından öğleden sonra sekiz buçukta Haydarpaşa'ya yönlendirildiği bilgisi Sirkeci Nokta Kumandanlığınca paylaşıldı. Haydarpaşa'ya ulaşan Taburun iaşe ve iskânı sağlandıktan sonra 15 Haziran 1916 tarihinde Sultan Çiftliğine hareketi gerçekleşti. Sultan Çiftliğine ulaştıktan sonra Sultan Çiftliği Nokta Kumandanlığının emri altına giren Tabur, Şile yolunda çalışacaktı. Bu aşamada öncelikli hedef, Kayalıdere-Ömerli Mezarlığ kısmının inşa ve tamirinin sağlanmasıydı (BDH. 2540-59-1-28; BDH. 2540-59-1-29; BDH. 2540-59-1-230; BDH. 2540-59-1-31; BDH. 2540-59-1-32; BDH. 2540-59-1-33; BDH. 2540-591-34; BDH. 2540-59-1-35; BDH. 2540-59-1-36; BDH. 2540-59-1-38).

\subsection{Taburun Faaliyetleri}

Başkent İstanbul'un bazı yollarının tamir ve inşası için Bolu İkinci Amele Taburunun tercih edilmesinde, yakın bir havalide bulunmasının etkisi büyüktür. Bünyesinde amelelerin dışında biri tabur, dördü bölük kumandanı ve birer hesap memuru, tabip ve iaşe subayı bulunan kafile, Şile yolunun tamiri için görevlendirilmişti. Bu görevlendirmede öncelik bakıma en muhtaç mevki olan Kayalıdere-Ömerli Mezarlı̆̆ 1 arasındaki kesimin tamiri ve inşasıydı. Bu bölgenin tamir ve inşasına memur edilen Nafia Mühendisi Hasan Sadeddin Bey, proje hakkında bilgiler paylaşmıştır. Nitekim Nişantaşı'ndaki Ordu Karargâhı ve Menzil Müfettişliği ile yaptığı yazışmalar sonucunda; Kayalıdere-Ömerli 
Mezarlığı arasındaki kısmın hazır hâle getirilmesinin ardından Ahmetli Karyesi ile Şile arasındaki kısmın onarılacağını belirtmiştir (BDH. 254059-1-2; BDH. 2540-59-1-3; BDH. 2540-59-1-5; BDH. 2540-59-1-7; BDH. 2540-59-1-10; BDH. 2540-59-1-11; BDH. 2540-59-1-12; BDH. 2540-591-16). Daha bölgeye intikal etmeyen Tabur için bir çalışma planının oluşturulmuş olması, savaş döneminde amele taburlarının önemini ortaya koymaktadır. Hatta bölgede farklı ve daha elzem görevlerin verileceğinden bahsedilerek çalışmaların süratle tamamlanması için sık sık teftişe maruz kalacaklarının dile getirilmesi, iaşenin sağlanmasında amele taburları kadar zamanın da kıymetini göstermektedir (BDH. 2540-59-1-19).

Yüzlerce kilometre yol kat ettikten sonra bitkin bir şekilde 15 Haziran 1916 tarihinde çalışma sahasına ulaşan Bolu İkinci Amele Taburunu bekleyen öncelikli problem konaklamaydı. Sevk bölgesinde askerî ve garnizon koğuşları bulunmadığından dolayı, geçici bir süre Paşaköyü'ne yerleştirilmişlerdir. Paşaköyü’nü cazip hâle getiren konaklamak için boş evlerin bulunması ve buradan bölükler şeklinde ayrılmanın kolay olmasıydı. Diğer taraftan merkez Paşaköy'ün dışında amelelerin bir kısmı da Ömerli Mezarlığı ile Çamcı Çiftliği yakınlarındaki Kayalıdere'deki çadırlara yerleştirildi. Taburun bölgeye gelişi dikkate alındığında kış aylarında çadırlarda konaklamak zorunda olanlara göre daha şanslı oldukları aşikârdır. Yalnız boş binaların konaklama için çadırlara oranla önemli bir firsat gibi durmasına karşın sıhhî açıdan çok da uygun oldukları söylenemez. Bu kapsamda gerek bölgede yaşanacak sağllk problemlerinin giderilmesi gerekse boş binaların dezenfekte edilmesi amacıyla Tabur revirinin Paşaköyü'nün yüksek bir yerinde ve Kayalıdere'ye yakın bir mahalde inşa edilmesi kararlaştııılmıştır (BDH. 2540-59-1-43; Özdemir, 1994: 127).

Bir müddet sonra yerleşme çalışmalarının tamamlanmasıyla Taburun işe başlama tarihi gündemi hayli meşgul etti. Bir tarafta, Taburun on gün Adapazarı'nda ve iki gün de Tuzla'da istirahat ettiği için yorgun olmadığı ve biran evvel işe başlaması gerektiğini dile getirenler vardı. Diğer yanda ise yolculuk dolayısıyla ciddi manada yorgun düştüklerini, dinlenmeleri gerektiğini savunanlar mevcuttu. Konuya ilişkin farklı beyanlara karşın Taburun işe başlaması istirahatten ziyade, bünyesinde bulunan alet ve edevatın tamir ettirilmesine ve talep edilen inşaat malzemelerinin teminine bağlıydı. Tabur, inşaat sahasına geldiğinde mevcut araç gereçler aşağıdaki gibiydi (BDH. 2540-59-1- 41; BDH. 2540-59-1-42; BDH. 2540-59-1-44; BDH. 2540-59-1-45; BDH. 2540-59-1-46; BDH. 2540-59-1-50): ${ }^{6}$

\footnotetext{
${ }^{6}$ Ayrıca Taburun Binbaşı Naci Bey ile Nafia Mühendisi Miralay Sadeddin Bey'in talimatlarına göre hareket edeceği bildirilmiştir. BDH. 2540-59-1-39.
} 
Tablo 1: Bolu İkinci Amale Taburunun İstanbul'a Geldiğinde Araç ve Gereç Toplamı

\begin{tabular}{lc}
\hline Malzeme & Adet \\
\hline Kazma & 155 \\
Kürek & 158 \\
Balyoz & 3 \\
Taş çekici & 8 \\
Lağım kaşı̆̆ı & 8 \\
Balta & 40 \\
Keser & 3 \\
Demir Tokmağ 1 & 5 \\
Mala & 8 \\
Burgu & 23 \\
\hline
\end{tabular}

Tablodan anlaşılmasa da Bolu İkinci Amale Taburunun mevcut araç gereçlerinin büyük bir kısmı tamire muhtaç ya da işe yaramaz olduğu ifade edilmektedir. Diğer taraftan Tabur sayısına oranla alet ve edevatın yetersiz olduğu göze çarpmaktadır. Bu sebeple ivedi olarak Taburun ihtiyacı olan malzeme listesi oluşturulmuştur. İlk etapta Tabur ihtiyacı için oluşturulan malzeme listesi aşağıdaki gibidir (BDH. 2540-59-1-47; BDH. 2540-59-1$48):^{7}$

Tablo 2: Taburun İstanbul'a Geldiğinde İhtiyaç Duyduğu Araç ve Gereç Toplamı

\begin{tabular}{lc}
\hline Malzeme & Adet/Kilo \\
\hline Kazma & 50 \\
Kürek & 50 \\
Büyük Balyoz & 10 \\
Taş çekici & 100 \\
El arabası & 50 \\
Sedyelik tahta & 50 \\
Taşçı kaması & 10 \\
Çivi & $20 \mathrm{~kg}$ \\
Demirci Ocağı & 1 \\
\hline
\end{tabular}

Bolu İkinci Amele Taburunun İstanbul'da üstleneceği görev ve ihtiyaç listesinin belirlenmesinin ardından malzemelerin taşınması için hayvan ihtiyacı doğmuştur. Sadece Bolu İkinci Amele Taburuna has olmayan bu durum, savaş boyunca karşılaşılan sıkıntıların başında gelmekteydi. Bu sırada hayvan depolarında bekletilen hayvanların talebe göre dağıtılması yazışmalarla mümkündü. Fakat yapılan yazışmalara rağmen mevcut depolardan öküz tedarikinin mümkün gözükmediği ve Adapazarı İkinci

7 İhtiyaç olarak sadece araç ve gereç değil aynı zamanda ayakkabı sıkıntısı da çekilmiştir. BDH. 2540-59-1-50. 
Amale Taburu tarafından bırakılan arabaların dahi yeterli olmadığı Erkan1 Harbiye' den bildirildi. Öküz ihtiyacının karşılanamamasına karşın bir merkep kolu tahsis edildi. Üçüncü Katar Heyeti'nin bu maksatla Palanozköy ve Ahmetli Ormanına hareketleri ve boş binalara yerleştirilmesi kararlaştırıldı. Ayrıca inşaat malzemelerinin taşınması için bir memur vasıtasıyla Üsküdar Nokta Kumandanlığına müracaat edilmesi gerekti. Böylelikle menzil teçhizat ambarından verilecek malzemenin de Ömerli’ye sevki sağlanacaktı.

Sultan Çiftliğine 15 Haziran 1916 tarihinde gelen kafile yaklaşık bir hafta sonra 23 Haziran 1916 tarihinde çukur kazmak ve taş kırmak suretiyle işe başlad1. Merkezi, reviri ve kileri Paşaköyü'nde bulunan Taburun (BDH. 2540-59-1-50; BDH. 2540-59-1-53; BDH. 2540-59-1-54; Özdemir, 1994: 130) Ömerli Mezarlığı-Kayalıdere'de işe başlamasının ardından Tabur mevcudunun artırılması konusunda talepte bulunuldu. Ancak ordu dairesinden altı yüz yirmi nefer istenilmesine karşın bu sayının çok altında, sadece yirmi kadar nefer gönderildi. Yine de Tabur mevcudunun az sayıda artmasından ya da çalışmaların ivme kazanmasından olsa gerek mevcut malzemelere ilaveten elli kazma, elli kürek, elli el arabası ve elli sedyelik tahtadan oluşan yeni bir ihtiyaç listesi oluşturuldu. Hatta bu listenin dişında daha teferruatlı aşağıdaki şu malzemelerin siparişi verilmiştir (BDH. 254059-1-49; BDH. 2540-59-1-55; BDH. 2540-59-1-56; BDH. 2540-59-1-57; BDH. 2540-59-1-58; BDH. 2540-59-1-59; BDH. 2540-59-1-60; BDH. 2540-59-1-61):

Tablo 3: Tabur için İhtiyaç Listesi

\begin{tabular}{lcl}
\hline Malzeme & Adet/Kilo Açıklama \\
\hline Balyoz & 12 & Dört kiloluk \\
Balyoz & 12 & Yedi ila dokuz kiloluk \\
Küskü & 8 & \\
Mil (Burgu) & 12 & $23-25$ milimetre çapında 1,5 metre uzunluğunda \\
Mil & 12 & Bir metre uzunluğunda \\
Taşçı kaması & 24 & \\
Seyyar demirci ocağ1 & 1 & Körük yahut vantilatörlü \\
Örs & 1 & \\
Demirci takımı & 1 & 2 maşa, 2 kıskaç, 2 keski, 2 balyoz \\
İngiliz anahtarı & 2 & \\
Hızar & 1 & Bıçağı için \\
Lağım kaşı̆̆ı & 8 & \\
İnce mil & 8 & \\
Kazma & 100 & \\
Kürek & 100 & \\
El arabası & 100 & Yoksa teskere imal edilmek üzere 100 tahta \\
Karfiçe & $40 \mathrm{~kg}$ & $3,5-4$ milimetre uzunluğunda 0,02 sihanında Karfiçe \\
\hline
\end{tabular}

${ }^{8}$ Karfiçe: Çekme demirden genişçe başli, orta boy çivi. 
Balyoz çeşidi ve miktarının artırılması Taburun bir müddet daha meşgalesinin taş kırmak olacağına işaret etmektedir. İhtiyaç malzemelerinin çeşitlendirilmesi ve sayıca artırılmasının ardından bölgeye intikali için bir merkep kolunun tahsisi hususu gündemi tekrar meşgul etti. Hatta çevreden odun tedariki için bu koldan birkaç merkebin kullanılması talebi de ihtiyacın gerekliliğini göstermekteydi. Nakliye kapsamında daha önce belirtilen Adapazarı İkinci Amale Taburuna ait olup Bulgurlu İmalathanesine teslim edilen altı öküz arabası ve hayvanların dışında Tabur bünyesinde bulunanlardan da istifade edilmesi söylendi. Dahas1 hayvanların koşum takımları yoksa tedarik edileceği belirtildi. Bu sırada nakliye vasıtalarına ihtiyacın hat safhaya ulaşmasının ardından Üçüncü Katar Heyeti'nin iki numaralı Konya-Ereğli kolu, Tabur emrine verildi.

Anadolu'nun farklı yerlerinde olduğu gibi görev süresince Taburun malzeme ihtiyacı gündemden hiç düşmemiştir. 25 Haziran 1916 tarihli bir telgrafta; talep edilenden yalnızca iki yüz doksan kürek ve kırk kazmanın Ömerli'ye sevk edildiği yazmaktadır. Dönemin koşulları ve farklı coğrafyalardaki cephelere hizmet eden taburlar göz önüne alındığında ihtiyacın karşılanamaması doğaldır. Nitekim Üsküdar-Şile yolunun bir kısmı için dahi altı yüz kazma, altı yüz taş çekici, lağımcı köskisi, mili ve kaşığıyla demirci ocağına ihtiyacın olduğu bildirilmiştir. Tüm taleplere karşılık bu sırada ambardaki malzeme sadece iki yüz otuz dört çekice tekabül ediyordu (BDH. 2540-59-1-51; BDH-2540-59-1-58; BDH. 254059-1-60; BDH. 2540-59-1-61).

Birtakım eksikliklere/imkânsızlıklara rağmen tüm hızıyla çalışmalarına devam eden Bolu İkinci Amale Taburu (BDH. 2540-59-1-62; 2540-59-164) 1916 yılının Temmuz ortalarına doğru, bulunduğu bölgeden binlerce kilometre uzaklıkta yer alan Amanos Demiryolu inşası için görevlendirildi. Mevcut karayolların ıslahı ya da yeniden inşasına ilaveten demiryolu hattı çalışmaları ikmal için elzemdi. Savaş sırasında taburların en fazla çalıştırıldığı hatlardan biri olan Toros-Amanos Demiryolu hattına görevlendirilmesinin ardından Bolu İkinci Amele Taburunun mevcudunun bin nefere ulaştırılması istendi. Bu sırada Tabur himayesinde bulunan nakliye vasıtalarının geri alınacağ edileceği bildirilmiştir. Bilhassa Tabur himayesine verilen merkep kolunun gönderilmeyeceği beyan edildi. Bu esnada Serbaytar Muavinliği, on kadar hayvanın iadesi konusunun Tabura iletildiğini duyurmuştur. Taburun ne zaman sevk edileceği ilk etapta bildirilmese de Paşaköyü'nde toplanması gerektiği söylendi. Çok geçmeden Paşaköyü'nde toplanan Taburun, kırk sekiz saat önce bildirilmesi hâlinde sevke hazır hale getirileceği vurgulandı (BDH. 2540-59-1-65; 2540-59-1-66; 2540-59-1-67; 2540-59-1-72; 254059-1-73; 2540-59-1-74; 2540-59-1-77; Özdemir, 1994: 147-148). Konuyla 
ilgili Tabur kumandanının yaptığ 1 açıklamada ise 15 Temmuz 1916 tarihinde öğleden sonra saat dörtte harekete hazır bulunacakları söylendi. Hatta saat dörde kadar erzakın alınması ve malzemenin yeni görev bölgesine taşınması için yetmiş yük hayvanı veya yirmi beş araba talep edildi. $\mathrm{Bu}$ talebin oluşmasında Tabur bünyesinde yeteri kadar hayvan bulunmaması ve Tabur envanterinin günden güne yeni malzemelerle artması etkili olmuştur (BDH. 2540-59-1-76). Osmanlı coğrafyasının değişik bölgelerinde savaş boyunca farklı ve yorucu görevlerde bulunan amele taburları için Mondros Mütarekesi, faaliyetlerin sonlanması demekti. Nitekim mütarekenin ardından ordunun terhisi amele taburlarını da kapsıyordu. ${ }^{9}$ Ancak Milli Mücadele döneminde amele taburları benzer gerekçelerle yeniden oluşturulmuştur. $\mathrm{Bu}$ husus, I. Dünya Savaş1 döneminde farklı mıntıkalarda gerçekleştirilen amele taburu uygulamasının haklılığını ve devamlılığını göstermektedir (Mutlu, 2011: 83-100).

\subsection{Taburun Nüfusu ve Amelelerin Meslek Türleri}

İstanbul'da Şile-Üsküdar yolu için görevlendirilen Bolu İkinci Amele Taburunun, yedi yüz ellinin üzerinde bir mevcutla hareketinin ardından zaman zaman sayısında değişikler meydana geldi. İhtiyaç dolayısıyla amele artışlarının gözlemlendiği Tabur hakkında bilhassa 16 Haziran 1916 tarihli belgede bin yirmi sekiz sayısı dikkat çekicidir. Zira bir aylık gibi bir zaman zarfinda üçte bir oranında amelenin Tabura katıldığı anlaşılmaktadır. Amele mevcudunda görülen bu değişikliği zamanla yol inşasında kullanılacak malzeme taleplerinin artması da desteklemektedir. Gerçi kimi talepler daha önce kullanılan malzemenin yetersizliğinin yanında kullanılamaz olduğuyla da alakalıydı. Bin yirmi sekiz sayısının açıklandığı tarihe yakın bir zamanda bin dört yüz doksan üç sayısı gibi farklı veri de mevcuttur.

Ancak bin yirmi sekiz mevcudunu veren 16 Haziran 1916 tarihli belge, Bolu İkinci Amele Taburu hakkında daha teferruatlı bilgiler sunmaktadır. Aynı zamanda amele taburlarında daha fazla gayrimüslim unsurların çalışırııldığı bilgisini revize etmemizi sağlamaktadır. Zira bu belgeden; Bolu İkinci Amele Taburunda altı yüz iki Müslüman, yüz iki Rum, elli dört Ermeni ve iki Yahudi olduğu anlaşılmaktadır. Tabur bünyesindeki Ermeni nüfusunun az olmasinda 27 Mayıs 1915 tarihli Sevk ve İsyan Kanunu'nu

9 Bolu İkinci Amele Taburunun Amonos'taki faaliyetlerine ve ne zaman lağvedildiğine dair araştırma eser ya da arşiv vesikasına rastlanılamamıştır. 
dikkate almamız gerekmektedir. ${ }^{10}$ Her ne kadar gayrimüslimler sayıca çok idiyseler de Sevk ve İskân Kanunundan sonra bu durum değişmiştir.

Tabur Kumandanı Yüzbaşı Mehmed Nihad'ın beyanına göre; ameleler farklı meslek kollarını temsil ediyordu. Bunlardan sekizi askerî personeldi. Her biri işinin ehli olan taşçı, duvarcı, hademe, doktor ve marangoz da Tabur bünyesindeki diğer meslek gruplarını oluşturuyordu. Savaş döneminde ordunun ihtiyacı olan zahire için ziraatta çalıştırılan ameleler de vard1. Bu sırada tarım işlerinde görevlendirilen yirmi altı işçinin tamamı Müslümandı. Bunların dışında alayda farklı görevlerde bulunanlar da vardı (BDH. 2540-59-1-40; 2540-59-1-70; 2540-59-1-71; 2540-59-1-75; Özdemir, 1994: 85, 119-125).

\subsection{Taburda Yaşanan Sıkıntılar}

Savaş boyunca amele taburları arasında yaşanan en büyük problemlerden biri asayiş zafiyetinden kaynaklanan firar olaylarıdır. Bir taraftan Osmanlı Devleti aleyhinde her türlü yapılanmaya destek veren Ermeni ihtilal cemiyetlerinin talimatları diğer taraftan Çarlık Rusya'nın Osmanlı Ermenilerini kullanmak düşüncesi silahlı ya da silahsız hizmet grubunda bulunan Ermenilerin çoğunun akıllarına biran evvel taburlarından firar etmeyi sokmuştur. Firar girişimleri daha çok terhis/nakil işlemleri sırasında asayiş zafiyetinin yaşandığı dönemlerde gerçekleştirilirdi. Savaş boyunca Anadolu'nun farklı yerlerindeki amele taburlarında rastlanan firar vakaları Bolu İkinci Amele Taburunda da zaman zaman yaşanmıştır. Tabura kayıtlı olmasına rağmen katılmayan ya da katıldıktan sonra firar edenlerden altıs1 Ermeni idi. Bu hususla ilgili ilginç detay, yüz dokuz kişiyle en fazla firar olayına karışanların Müslüman olmasıdır. Müslümanları yirmi üç firar vakasıyla Rumlar, altı vaka ile Ermeniler ve bir vaka ile de Bulgar unsurlar takip etmiştir. Dahası Divan-1 Harbe intikal eden üç Müslüman Tabura kayıtlıydı (BDH. 2540-59-1-40; Özdemir, 1994: 95-98).

Amele taburlarında çalışan efradın karşılaştığı önemli sorunlardan bir diğeri salgın hastalıklardı. Çoğunlukla 20-45 yaş grubunda olan ve birlikler hâlinde çalışmak zorunda kalan amelelerde yetersiz beslenme, uzun süren yolculuklar ve ağır çalışma şartları, hastalık vakalarını ortaya çıkarmaktaydı. Bilhassa binin üzerinde çalışanı bulunan Taburun

${ }^{10}$ Bkz: Mehmet Süme-Cemal Sezer, "Bolu'da Yaşayan Ermeniler (1840-1920)", Abant İzzet Baysal Üniversitesi Ĕ̌itim Fakültesi Dergisi, 15 (USBES Özel Sayıs1 I), 2015, s. 45-51; Diğer taraftan Takvor Hopyan, Milleti Sadıka'dan 1915 Ermeni Tehcirine Pederimin Anıları adlı eserinde Bolu'da yaşayan Ermenilerin 27 Mayıs 1915 tarihli kanuna tabi tutulmadığına dair bilgiler mevcuttur. 
envanterinde beslenme hususunda şu araçların bulunması sayıya oranla yetersizliği ortaya koymaktadır.

Tablo 4: Taburun Envanterindeki Konaklama ve İaşe ile ilgili Liste

\begin{tabular}{lc}
\hline Malzeme & Miktarı \\
\hline Çadır & 28 \\
Kazan & 14 \\
Kepçe & 3 \\
Tava & 2 \\
Kevgir & 1 \\
Çini Karavana & 97 \\
Teneke Karavana & 21 \\
\hline
\end{tabular}

Amelelerden bir kısmının boş binalarda konaklamasına karşın sadece yirmi sekiz kadar çadırın bulunması, gayrisıhhî durumlara davetiye çıkarmıştır. Hatta konaklamanın yanında yeterli beslenmenin tam olarak sağlanamadığı ortadadır. Zira Taburun nüfusunu besleyen yemekhane envanterinin eksikliği bu durumu açıklar niteliktedir.

Bolu İkinci Amele Taburunun Şile havalisindeki çalışma süresince yaralanma ya da bölgedeki salgın hastalık vakalarından olsa gerek elli dört kişi tedavi altına alınmıştır. Revirdeki ameleler arasında nüfus potansiyellerine paralel olarak en fazla hastalıklı durum Müslüman unsurlar arasında görülmüştür. On dört Rum ve iki Ermeni de çeşitli sağlık problemleri gerekçesiyle hastanede müşahede altına alınmıştır. Sağlık problemleri dolayısıyla hava değişimine ihtiyaç duyan Tabur personelinin sayısı otuz sekiz kadardı. Bunların büyük çoğunluğunu Müslüman ameleler oluşturuyordu. $\mathrm{Bu}$ arada amele taburlarının bir kısmında personel yetersizliğinden dolayı sağlık ekibi ya da doktor bulunmamakta iken Bolu İkinci Amele Taburunda böyle bir sıkıntı yaşanmamıştır. Ancak Taburun İstanbul'daki görev yerine varmasından kısa bir süre sonra Tabip Agop ile hesap memuru Feyzi Efendinin Tabura katılmadıkları, durumun adreslerine bildirilmesi ve dâhil oldularsa tutuklanmaları istenmiştir. İlerleyen dönemlerde ise Tabur bünyesinde doktor ve hesap memurunun bulunduğu kayitlarda geçmektedir.

Hava şartlarının yanında savaş koşullarına göre çalışılması temizlik ve barınma imkânlarının yetersizliği hastalıkların sirayetini kolaylaştırmıştır. Hatta Ömerli bölgesine gelmeden önce merkep kolları efradı arasında bit görüldüğünden hamam inşası zorunlu hâle gelmiş, dışarıda yıkanmak zorunda kalanlar ise zatürreye yakalanmışlardır (BDH. 2540-59-1-40; BDH-2540-59-1-50).

Yol yapımı ve tamiri dışında ziraî faaliyetlerde bulunan amele taburlarının karşılaştığı başka bir sıkıntı ise tarımsal verimdeki düşüklüktür. Bir 
taraftan erkek nüfusunun orduya katılması diğer taraftan geride kalan kadın ve yaşlıların gerekli katkıyı verememesi yani insan gücünün yetersizliği tarımsal faaliyetleri sekteye uğratmıştır. Dolayısıyla Anadolu'nun farklı yerlerinde ordu bünyesinde bulunan amele taburları için yeni iş sahası iaşe faaliyetleri olmuştur. Nitekim zaman zaman çekirge istilalarının üretimi düşürmesine rağmen askeri kıtaların yanında amele taburlarının da hasat döneminde gerekli yardımı yaptıkları görülmüştür (BOA. DH. ŞFR. 76/156; Özdemir, 1994: 159-160).

\section{Sonuç}

Savaşlar olağanüstü şartları barındırdığından Osmanlı devlet erkânı, çok katılımlı uzun bir mücadele dönemi olan I. Dünya Savaşı için, benzer örnekleri daha önce de görülen geri hizmet birimleri oluşturmuşlardır. Anadolu'nun farklı yerlerinde oluşturulan ve sayıları kimi zaman yüzlerle kimi zaman da binlerle ifade edilen amele taburlarıyla hem savaşın etkisini en aza indirmek hem de sosyal devlet anlayışını devam ettirmek için mücadeleler verilmiştir. Her devlet için savaşlar ülke topraklarını moloz yı̆̆ını haline getirebilecek yıkıcılıkta süreçleri barındırır. Ancak Osmanlı Devleti'nde kısmen de olsa savaştan sonra sosyo-kültürel hayatın sekteye uğramadan devamlılığında amele taburlarının gayreti ve yoğun çalışmalarının etkisi büyüktür. Çünkü savaş sırasında tahrip olan yolların tamirinin yanı sıra yeni ulaşım kanallarının açılması ve demiryolu hatlarının 1slahında ilk akla gelen hizmet birimi amele taburları olmuştur. Böylelikle halk, barış döneminde ulaşım imkânlarının sağlandığı, gündelik işlerine devam edebildiği hazır bir sosyal çevre ile karşılaşmıştır.

Beslenme ve konaklama imkânları, koşullar gereği çok sağlıklı olmamasına rağmen savaş dönemi boyunca ziraî üretim noktasında amele taburlarının hatırı sayılır katkıları olmuştur. Zira bu süreçte erkek nüfusun cephelerde oluşu; kadın, çocuk ve yaşlıların ise üretime yeterince katkı verememelerine karşın amele taburlarının tarım arazilerinde ekim ve hasat işlerini gerçekleştirerek ordunun iaşesine ciddi katkı sağladıkları görülmüştür. Savaş boyunca farklı cephelerde savaşmak zorunda kalan milyonlarca askerin iaşesinde ambarlardaki stokların dışında, cephe gerisindeki halkın ve amele taburlarının ziraî faaliyetleri etkili olmuştur.

Amele taburlarının teşekkülü firar, itaatsizlik ve casusluk gibi bazı olumsuzluklara rağmen teşkilatlı ve deneyimli bir devlet tecrübesine örnek oluşturmaktadır. Taburların teşkil çalışmaları, faaliyetleri ve taşkınlıklarının önlenmesi, devlete maddi bir külfet getirmiş olsa da gerçekleştirilen çalışmaların devlete çok daha fazla getirisi olmuştur. Öte yandan bu taburların yapısı, Ermeni diasporasının söylemlerini boşa çıkaran somut bir göstergedir. Çünkü savaş boyunca amele taburlarının 
bünyesinde Ermeni unsurlar da yer almıştır. 27 Mayıs 1915 tarihli Sevk ve İskân Kanunu'na tabi tutulanların dışında devletlerine sadık bir şekilde orduda yer alan ve görevini layıkıyla gerçekleştiren Ermenilerin sayısı, önceki yıllara oranla azalmış olmasına rağmen yine de hatırı sayılır orandadır. Ayrıca Ermeniler savaş ortamında yol yapım ve onarım çalışmalarına katılarak ordunun durumu, harekâtları gibi stratejik bilgilere sahip olmalarına karşın görevlerine devam ettirilmişlerdir. Bu durum Osmanlı yönetiminin bir taraftan Ermenilere ve diğer gayrimüslimlere her ne kadar şüpheyle yaklaşsa da hâlen güvendiğini ya da onları bir şekilde kontrol altında tuttuğunu gösterirken diğer taraftan bugün ortaya atılan Ermeni iddialarının asılsız ve mesnetsiz olduğunu ortaya koymaktadır.

\section{Kaynaklar}

Arşiv Belgeleri

Başbakanlık Osmanlı Arşivi

BOA. DH. EUM. KLU. 6/39.

BOA. DH. İ. UM. 59/1.

BOA. DH. ŞFR. 76/156; 472/53.

Genelkurmay ATASE Arşivi

BDH. 2540-59-1; 2540-59-1-1; 2540-59-1-4; 2540-59-1-6; 2540-59-1-8; $2540-59-1-9 ; 2540-59-1-13 ; 2540-59-1-14 ; 2540-59-1-15 ; 2540-59$ $1-17$; 2540-59-1-18; 2540-59-1-23; 2540-59-1-26; 2540-59-1-27; $2540-59-1-28 ; 2540-59-1-29 ; 2540-59-1-31 ; 2540-59-1-32 ; 2540-$ $59-1-33 ; 2540-59-1-34 ; 2540-59-1-35 ; 2540-59-1-36 ; 2540-59-1-$ 38 ; 2540-59-1-2; 2540-59-1-3; 2540-59-1-5; 2540-59-1-7; 2540-59$1-10 ; 2540-59-1-11 ; 2540-59-1-12 ; 2540-59-1-16 ; 2540-59-1-19$; $2540-59-1-43 ; 2534-32-1-31 ; 2540-59-1-41 ; 2540-59-1-42 ; 2540-$ $59-1-44 ; 2540-59-1-45 ; 2540-59-1-46 ; 2540-59-1-50$; 2540-59-1$39 ; 2540-59-1-47 ; 2540-59-1-48 ; 2540-59-1-50 ; 2540-59-1-53$; 2540-59-1-54; 2540-59-1-49; 2540-59-1-55; 2540-59-1-56; 2540$59-1-57$; 2540-59-1-58; 2540-59-1-59; 2540-59-1-60; 2540-59-1$61 ; 2540-59-1-51 ; 2540-59-1-58 ; 2540-59-1-60 ; 2540-59-1-61$; $2540-59-1-62$; 2540-59-1-64; 2540-59-1-65; 2540-59-1-66; 2540$59-1-67 ; 2540-59-1-72 ; 2540-59-1-73 ; 2540-59-1-74 ; 2540-59-1-$ 76 ; 2540-59-1-77; 2540-59-1-40; 2540-59-1-70; 2540-59-1-71; 2540-59-1-75; 2540-59-1-40; 2540-59-1-50. 
Araştırma Eserler

Beyoğlu, S. (2014). “Ermeniler Amele Taburlarında”, Yeni Türkiye, 60, s. 1-17.

Evcin, E. (2011). Birinci Dünya Savaşı'ndan Türkiye Cumhuriyeti'nin Kuruluşuna Bolu ve Çevresi ve İz Bırakanları, Atatürk Üniversitesi Sosyal Bilimler Enstitüsü Basılmamış Doktora Tezi, Ankara.

Gülboy, B. (2004), Birinci Dünya Savaşı Tarihi, Altın Kitaplar, İstanbul.

Güler, A. (1996), Türkiye’de Gayri Müslimler (Sosyo-Ekonomik Durum Analizi), Ankara.

Hacısalihoğlu, M. (2007), “Osmanlı İmparatorluğundan Zorunlu Askerlik Sistemine Geçiş: Ordu Millet Düşüncesi”, Toplumsal Tarih, 164, s. 58-64.

Hopyan, T. (2017), Milleti Sadıkadan 1915 Ermeni Tehcirine Pederimin Anıları, Puslu Yayınevi, İstanbul.

Karagöz, M. (2019), “Birinci Dünya Savaşı'nda IV. Ordu Menzilinde Amele Taburları”, Güvenlik Stratejileri, C. 15, S. 30, s. 379-415.

Kurtaran, U. (2012), “Osmanlı Seferlerinde Organizasyon ve Lojistik”, Turkish Studies, Volume 7/4, s. 2269-2289.

Lüleci, A. (2017), "Savaşın Gölgesinde Ermeni Vahan Çetesi ve Faaliyetleri" Uluslararası Gazi Süleyman Paşa ve Kocaeli Tarihi Sempozyumu-III, Kocaeli, s. 1401-1411.

Mutlu, C. (2007), Birinci Dünya Savaşı 'nda Amele Taburları (1914-1918), IQ Kültür Sanat Yayınc1lık, İstanbul.

Mutlu, C. (2011), İstiklal Savaşında Geri Hizmet Birlikleri, Güneydoğu Avrupa Araştırmaları Dergisi, S. 20, s. 83-100.

Özdemir, Z. (1994), I. Dünya Savaşında Amele Taburları, Gazi Üniversitesi Sosyal Bilimler Enstitüsü Basılmamış Yüksek Lisans Tezi, Ankara.

Süme, M. ve Sezer, C. (2015), "Bolu'da Yaşayan Ermeniler (1840-1920)", Abant İzet Baysal Üniversitesi Eğitim Fakültesi Dergisi, 15 (USBES Özel Sayısı I), s. 35-63.

Şişmanoğlu Şimşek, Ş. (2015), "Benden Selam Söyle Anadolu’ya: Birinci Dünya Savaşı'nda Asker Olmak”, Uluslararası Sosyal Araştırmalar Dergisi, C. 8, S. 39, s. 208-221. 
